\title{
Effect of ZnO Thin Films on Survival of Pseudomonas Cells
}

\section{Ivanova IA ${ }^{1 *}$, Tasheva-Terzieva $E^{2}$, Angelov $\mathrm{O}^{3}$, Krusteva $\mathrm{L}^{4}$, Andonova I', Papazova $\mathrm{K}^{4}$, Dimova-Malinovska $\mathrm{D}^{3}$ and Dushkin $\mathrm{C}^{4}$}

${ }^{1}$ Department of General and Industrial Microbiology, Faculty of Biology, University of Sofia "St. KI. Ohridski", 1164 Sofia, Bulgaria

${ }^{2}$ Department of Zoology and Anthropology, Faculty of Biology, University of Sofia "St. KI. Ohridski", Bulgaria

${ }^{3}$ Central Laboratory of Solar Energy and New Energy Sources, Bulgarian Academy of Sciences, Sofia, Bulgaria

${ }^{4}$ Laboratory of Nanoparticle Science and Technology, Department of General and Inorganic Chemistry, University of Sofia "St. KI. Ohridski", Bulgaria

\begin{abstract}
Thin films of $\mathrm{ZnO}$ nanoparticles obtained by magnetron sputtering deposition and wet chemical methods are investigated for their antibacterial effect on Gracilicutes- bacteria Pseudomonas putida. This bacterium is used as a sensitive standard in an international water quality test, ISO 10712:1995. It was chosen for toxic assessment of thin $\mathrm{ZnO}$ films, prepared by magnetron sputtering, sol-gel dip coating and chemical bath deposition methods. Washed and stained with Dead/Live bacterial kit suspension is evenly distributed on thin $\mathrm{ZnO}$ films and the survived cells are counted every 2 hours. Two microbiological methods are used: direct counting with epifluorescent microscope Leika DM 5500B and cultivation in nutrient medium. The results are processed with different statistical methods and show bactericidal effect of thin $\mathrm{ZnO}$ films. The surface relief of thin nanostructured film is crucial for the antibacterial effect and the fastest bactericidal effect demonstrates the $\mathrm{ZnO}$ film obtained by sol-gel dip coating.
\end{abstract}

Keywords: $\mathrm{ZnO}$ films; Wet chemical methods; Magnetron sputtering; Dead/Live bacterial kit

\section{Introduction}

$\mathrm{ZnO}$ nanoparticles and thin films have broad application in biology [1], medicine [2,3] etc. Nanoparticles (NPs) of $\mathrm{ZnO}$ are widely used in cosmetics and sunscreens [4] (2007), but also in solar-driven self-cleaning coatings [5] and textiles [6]. Currently ZnO NPs are already produced in industrial amounts [7]. Toxicological studies show increased toxicity of nanoparticles (size $<100 \mathrm{~nm}$ ) on bacteria with decreasing of their size [8]. Franklin and co-authors [9], have studied the toxicity of $\mathrm{ZnO}$ nanoparticles to $P$. subcapitata and have determined the concentration of the dissolved $\mathrm{Zn}$ ions derived from $\mathrm{ZnO}$. It is found that the toxicity of $\mathrm{ZnO}$ particles and $\mathrm{ZnCl}_{2}$ is due to the dissolved $\mathrm{Zn}^{2+}$ ions [9]. Heinlaan and co-authors [10] established lethal/effective concentrations $\mathrm{L}(\mathrm{E}) \mathrm{C} 50$ for bulk $\mathrm{ZnO}$, nanoZnO and $\mathrm{ZnSO}_{4} .7 \mathrm{H}_{2} \mathrm{O} 1.8,1.9,1.1 \mathrm{mg} . \mathrm{l}^{-1}$, respectively, for Vibrio fischeri. They report that the toxicity is due to dissolved $\mathrm{Zn}$ ions as proved with recombinant $\mathrm{Zn}$-sensitive bacteria [10]. However, other group has reported that the reason for the toxic effect is the damaging of cell wall and membrane [11]. Their conclusions are that $\mathrm{ZnO}$ nanoparticles are effective for inhibition of both Gram-positive and Gram-negative bacteria. The antibacterial activity against spores that are hightemperature and high-pressure resistant is reported by Huang [12]. The higher concentration and the larger surface area of the $\mathrm{ZnO}$ nanoparticles have better antibacterial activity according $\mathrm{Li}$ et al. [13]. Li and colleagues reported antibacterial activity of $\mathrm{ZnO}$ films on different (Gracilicutes and Firmicutes) bacteria too [14].

The main mechanism of toxicity of NPs is thought to be via oxidative stress (OS) [15] that damages lipids, carbohydrates, proteins and DNA $[15,16]$. Lipid peroxidation is considered most dangerous as leading to alterations in cell membrane properties which in turn disrupt vital cellular functions [17]. Xie and co-authors [18], have studied the toxicity of $\mathrm{ZnO}$ nanoparticles to Campylobacter jejuni and have determined the morphological and some gene expression changes. It is suggested that the antibacterial mechanism of $\mathrm{ZnO}$ nanoparticles is due to disruption of the cell membrane and oxidative stress to Campylobacter jejuni.

It has long been established that cultivable bacteria represent only a small fraction of all bacteria present in natural habitats [19]. A lot of different methods for precise cells count determination are used, one of which is epifluorescent microscopy and fluorescent dyes. Since acridine-orange is not reliable enough to distinguish live from dead cells in the environment $[20,21]$ a DEAD/LIVE kit of Promega Company (USA) is used in our experiments. The kit consists of two dyes to which the bacterial cell wall and membrane have different permeability: propidium iodide and Syto9. Red stained cells are counted as dead and green are considered as live. Stocks [22] determines the ratio of propidium iodide to DNA quantity as $0,4: 1$. We used this ratio in our experiments to observe the changes in live and dead cells in interaction with thin $\mathrm{ZnO}$ films.

In this work, we investigate the antibacterial effect of undoped $\mathrm{ZnO}$ thin films (ZTFs) obtained by different methods on the test strain Pseudomonas putida ATCC 12633 as a first step in the construction of indoor air quality test sensor.

\section{Materials and Methods}

\section{Prepearing of ZTFs - $\mathrm{ZnO}$ deposition methods}

Magnetron sputtering (MS): The ZTFs are prepared on glass substrates by radio frequency (r.f.) magnetron sputtering (MS) of a $\mathrm{ZnO}$ ceramic target $(100 \mathrm{~mm}$ disc $)$ in atmosphere of $\mathrm{Ar}(0.5 \mathrm{~Pa})$ at substrate temperature of $500^{\circ} \mathrm{C}$, and r.f. power of $180 \mathrm{~W}$. The film thickness is about $600 \mathrm{~nm}$. SEM pictures were obtained by JSM840A JEOL with $\mathrm{LaBa}_{6}$ cathode. Other investigations are described by Dimova-Malinovska et al. [23].

*Corresponding author: Dr. Ivanova IA, Department of General and Industrial Microbiology, Faculty of Biology, 1164 Sofia, Bulgaria, Tel: +359885933242, +359898753883; E-mail: ilivanova@biofac.uni-sofia.bg

Received August 20, 2012; Accepted October 16, 2012; Published October 20, 2012

Citation: Ivanova IA, Tasheva-Terzieva E, Angelov O, Krusteva L, Andonova I, et al. (2012) Effect of ZnO Thin Films on Survival of Pseudomonas Cells. J Nanomed Nanotechol 3:148. doi:10.4172/2157-7439.1000148

Copyright: (C) 2012 Ivanova IA, et al. This is an open-access article distributed under the terms of the Creative Commons Attribution License, which permits unrestricted use, distribution, and reproduction in any medium, provided the original author and source are credited. 
Sol-gel dip coating (SGDC): Zinc acetate, 2-methoxyethanol and mono-ethanolamine are used as precursors. The glass substrates (ISOLAB-Germany) are coated with five deposit layers as every next layer was placed after the drying of the previous in air at $80^{\circ} \mathrm{C}$ for $15 \mathrm{~min}$. The final annealing is carried out at $500^{\circ} \mathrm{C}$ for 1 hour and the final films' thickness is about $1 \mu \mathrm{m}$. The films are investigated by SEM-JSM- 5510 JEOL operating at accelerating voltage of $10 \mathrm{kV}$ according to Kaneva et al. [24]. XRD spectra are presented in Ivanova ei et al. [25]

Chemical bath deposition (CBD): A wet chemical method is used to obtain $\mathrm{ZnO}$ films in two steps: deposition of seeds followed by the growth of nanorods on them. The glass substrates are covered up in four cycles with zinc acetate dissolved in ethanol by spin coating. The coated substrates are rinsed with water and dried at room temperature followed by annealing at $320^{\circ} \mathrm{C}$ for $20 \mathrm{~min}$. That procedure is repeated twice before the final growth of $\mathrm{ZnO}$ nanowires to be completed. After that the seeded substrates are placed in aqueous solution of zinc nitrate and methenamine and heated up in a closed vial at $87^{\circ} \mathrm{C}$ for $3 \mathrm{~h}$. After the heating, the thin films are removed, rinsed with distilled water, and placed in a new batch of precursor solution. The nanowires growing process and other investigations of obtained films are described in Peshkova et al. [26].

\section{Surface morphology of ZTFs}

The surface morphology of all tested films is investigated by atomic force microscopy (AFM) and scanning electron microscopy (SEM) on a JEOL JSM-6500F microscope, using an electron beam energy of 5-20 $\mathrm{keV}$ and an emission current of $64 \mathrm{l} \mathrm{A}$. Prior to investigation, the thin $\mathrm{ZnO}$ films samples are coated with a uniform goldlayer to ensure good electrical conductivity.

\section{Antibacterial tests}

Test culture: The test culture used in the study is Pseudomonas putida (ATCC 12633) which is provided by the Bulgarian National Bank of Industrial Microorganisms and Cell Cultures.

Agar diffusion method: The test culture is cultivated in a nutrient broth (Conda, Spain) on a rotary shaker $(180 \mathrm{rpm})$ at $25^{\circ} \mathrm{C}$ overnight followed by the pre-culturing of bacteria in fresh medium till the optical density of 0.02-0.03 was detected spectrophotometrically at $610 \mathrm{~nm}$. The bacterial suspension is used for inoculation $(100 \mu \mathrm{l})$ of nutrient agar in Petri dishes. The ZTFs are sterilized by flaming and placed after cooling on inoculated agar. The dishes are cultivated for $24-48 \mathrm{~h}$ at $25^{\circ} \mathrm{C}$. In the other case, the sterilized ZTFs is covered with melted and chilled to $45^{\circ} \mathrm{C}$ inoculated with test culture nutrient agar, and cultivated till 72-94 $\mathrm{h}$.

Microscope counting: The samples for microscope counting of bacterial cells are prepared as the sterilized ZTFs are placed on object glasses in sterile Petri dishes and covered with $10 \mu \mathrm{l}$ of Pseudomonas putida washed cell suspension $\left(10^{8} \mathrm{CFU} / \mathrm{ml}\right)$ in exponential phase mixed with Dead/Live bacterial viability kit (Promega) in ratio 5:1 according to Stocks [22].

Bacterial culture in exponential phase is obtained by stepwise recultivation of $P$. putida in synthetic broth (ISO 10712:1995) for $12 \mathrm{~h}$ and two times of 4 hours on a rotary shaker $(180 \mathrm{rpm})$ at $25^{\circ} \mathrm{C}$. The bacterial pellets are collected by centrifugation $(10,000 \mathrm{rpm}$ for 8 $\mathrm{min}$ ) and re-suspended gently in sterile physiological solution, and the procedure is repeated three times to escape the effect of the nutrient medium.

Six replicates are prepared for every type of ZTFs (MC, SGDC and
$\mathrm{CBD}$ ), and eight replicates for control (without $\mathrm{ZnO}$ nanoparticles on object glasses). All object glasses and cell suspension are kept in dark at room temperature to minimize the color bleaching of kit.

Bacterial images (20 per glass) are photographed with epifluorescence microscopy camera (Leika DM55000; 400 X) in every two hours as the first two control glasses are photographed immediately after the beginning to quantify the live and damaged cells at the time zero. The number of cells is counted using the size of the image, the average number of bacteria per field and the volume of cell suspension, as well as a culturing method. The number of live cells in the images is defined as the sum of yellow and green cells, while the red and orange cells are counted as dead and damaged cells according to Liu [27].

After photography, each variant is rinsed in sterile microbiological box with $1 \mathrm{ml}$ of sterile water to remove the bacteria from the glass. Decimal dilutions are prepared by the obtained bacterial suspensions, and they are used for inoculation $(100 \mu \mathrm{l})$ of nutrient agar (without nanoparticles) for counting of bacteria survived on the ZTFs. The Petri dishes are cultivated in dark at $25^{\circ} \mathrm{C}$ and the quantity of bacterial colonies is counted on 24th and 48th hours.

SEM images are prepared of thin films cultivated for $24 \mathrm{~h}$ in bacterial suspension and dried in sterile petri dish at room temperature.

Biostatistical analysis: Statistics are performed using SigmaPlot Version 12.0 (Systat Software, Inc.). Antibacterial effects of ZTFs are evaluated using the ratio of live/dead cells denoted in the text as RLD. The main sample statistics (minimum, maximum, mean, standard error of mean, standard deviation and median) are computed for the live/dead ratio for all groups. The comparison between the replicas is made by means of the Student t-test or Mann-Whitney U-test, when normality test (Kolmogorov-Smirnov and Shapiro-Wilk) failed. The change in the live/dead ratio during the experiment is analyzed with Kruskal-Wallis ANOVA on Ranks. The same test is used for evaluation of the differences between the antibacterial effect of the films. The Pairwise Multiple Comparison Procedures are applied - Tukey test or Dunn's test, for groups with unequal size.

\section{Results and Discussion}

\section{Magnetron sputtering}

Figure 1 shows AFM and cross section SEM pictures of $\mathrm{ZnO}$ thin films. The films have columnar structure with pyramidal ends of the columns at the film surface. The morphology of other thin films is presented at in Figures $2 \mathrm{c}$ and 3. Magnetron sputtered $\mathrm{ZnO}$ films have relatively smooth surface, as the films obtained by sol-gel dip coating have a very wrinkled and uneven surface (Figure 3a,3b,3c,3d). At first films are tested with simple agar diffusion method for bactericidal effect. As it is seen from Figure $2 \mathrm{c}$ the $\mathrm{ZnO}$ thin films obtained by magnetron sputtering deposition did not show any antibacterial effect. In contrast, growth stimulation of bacteria is observed, expressed as white zones on agar around the films (Figure 2a,2b). On SEM pictures the Pseudomonas putida cells look intact - no deformed cells and no cellular material can be seen on Figure2c.

\section{Sol-Gel Dip Coating (SGDC)}

The morphology of thin films is presented in Figures $3 \mathrm{a}$ and $3 \mathrm{~b}$. The films obtained by sol-gel dip coating have a very wrinkled and uneven surface. The thickness of the deposited films is about 2000-3000 nm. More detailed description and spectra are presented in Kaneva et al. [24]. 

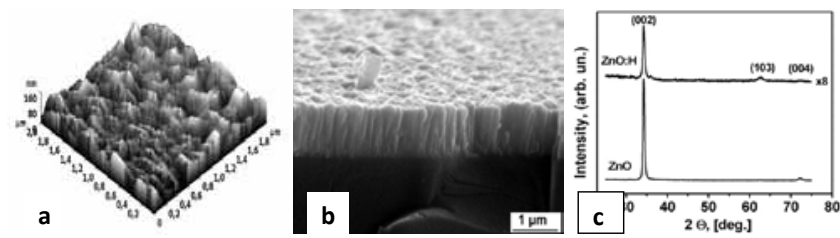

Figure 1: (a): AFM picture (3D image, $2 \times 2 \mu \mathrm{m})$; (b): SEM cross section picture of the deposited thin $\mathrm{ZnO}$ films by magnetron sputtering and (c): XRD spectra of thin films $\mathrm{ZnO}\left(\mathrm{T}_{\mathrm{s}}=500^{\circ} \mathrm{C}\right)$ and $\mathrm{ZnO}: \mathrm{H}\left(\mathrm{T}_{\mathrm{s}}=400^{\circ} \mathrm{C}\right)$ prepared by magnetron sputtering.

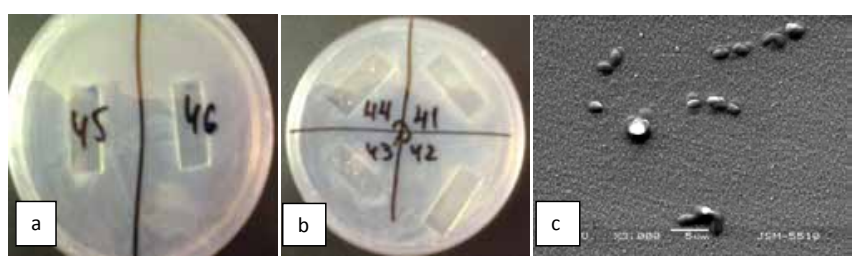

Figure 2: White zones around the deposited thin films by MSD - (a), (b) and (c) - SEM picture of $\mathrm{ZnO}$ film surface with Pseudomonas cells after $24 \mathrm{~h}$ of cultivation.
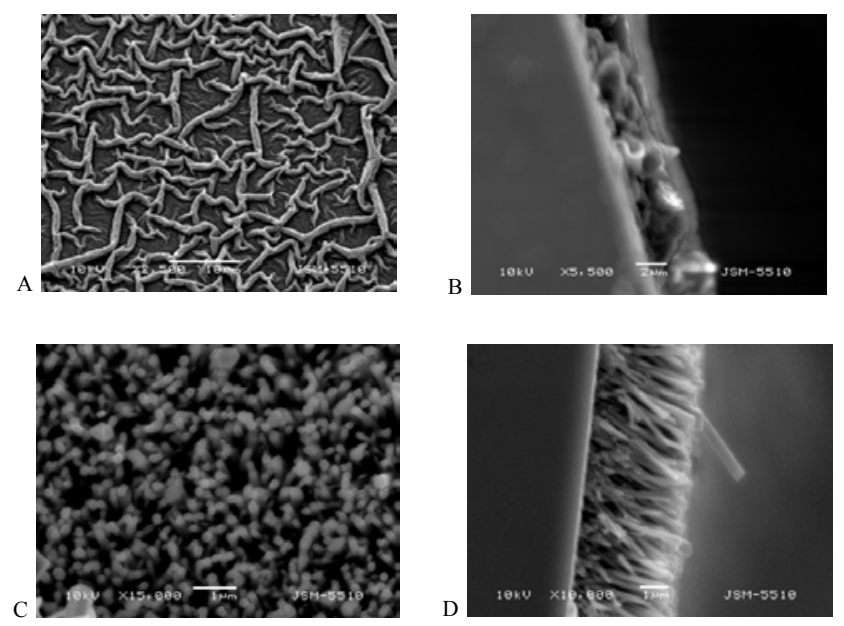

Figure 3: SEM pictures of the $\mathrm{ZnO}$ thin films deposited by sol-gel dip coating upper side (A), Cross section (B) and chemical bath deposition: upper side (C) and cross section (D).

\section{Chemical bath deposition (CBD)}

$\mathrm{ZnO}$ nanowires with hexagonal crystal structure and varying density, alignment and size are obtained on the substrates. The optimal method for synthesis of $\mathrm{ZnO}$ nanowires with high density and uniformity and aligned along the $\mathrm{z}$-axis is a seed deposition by spin coating on glass substrates and chemical-bath aftergrowth. This synthesis route has a good reproducibility. The thickness of the deposited films is about $3000 \mathrm{~nm}$ (Figures $3 \mathrm{c}$ and 3d). XRD spectra are presented and described in Pehskova and co-authors [26].

\section{Cells count}

Microscopic cells count of Pseudomonas cells suspension, stained with Dead/Live bacterial kit ${ }^{\circledR}$ on usual object glass without $\mathrm{ZnO}$ films is performed as a control. The green and yellow cells counted as live are more than red almost 3 times at the start of the experiment ( 0 hour). At the second hour the live cells are almost four time more than dead cells and this can be explained by formation of stable cell wall around the new formed daughter cells, as the bacteria are in exponential phase. The ratio between live and dead cells in the control variants show a normal distribution in the zero and the second hour in both tested replicas. At the fourth hour, the red cells are more than green and yellow and their ratio is 9:10. This can be explained by a processes of loss of the integrity of the cell membrane occurring during the cell division and penetration of propidium iodide in the dividing cells. At the sixth hour there is another increase of the number of green cells, but not as high as in the second hour, may be as a result of the start of second cells' division. Using t-test at the $4^{\text {th }}$ hour is established that differences between the two replicas in control variant are not significant. Similar are the results for the sixth hours. From the results concerning the survived cells in nutrient medium it could be seen, that the number of cells in the control variant is close to that of the green, yellow and orange cells together or higher. So, at the start of the experiment the quantity of live cells forming colonies on nutrient agar is between $5 \times 10^{5}$ and $6 \times 10^{5}$ $\mathrm{CFU} / \mathrm{ml}$. At the $4^{\text {th }}$ hour the quantity of live cells is the same, but at the $6^{\text {th }}$ hour the live cells, which form colonies on nutrient agar are $8 \times 10^{6} \mathrm{CFU} / \mathrm{ml}$. The formed biofilm in Figure 7a prove, that the glass, used as control is inert and surrounding conditions are suitable for the cell multiplication till $6^{\text {th }}$ hour (end of the experiment) as microscopic counting shows (Figure 4).

Kruskal Wallis test shows a significant difference between the values of live/dead cells ratio during the time of the experiment $(H=18.51$, $P<0.001)$. That ratio gradually decreases from the first hour to the $4^{\text {th }}$ hour (0:9) and after that it increases slightly to sixth hour (1:77). From a physiological standpoint, the observation can be explained by the state of the bacterial culture. Cells are subjected to the impact of the treatment (centrifugation and washing) in a phase of exponential growth. It can be assumed that most of them duplicate their DNA and are ready to divide. Reduction of the ratio live/dead cells at the $4^{\text {th }}$ hour suggests some changes in the integrity of the cell wall, which is associated with the process of the mother's cell separation into two daughter's cells. The new increase in the ratio live/dead cells at the $6^{\text {th }}$ hours suggests about the complete process of division, separation and formation of the rigid cell wall around the new daughter's cells, impermeable to propidium iodide (Figure 4, Table 1).

The behavior of Pseudomonas putida cells on thin $\mathrm{ZnO}$ film is very

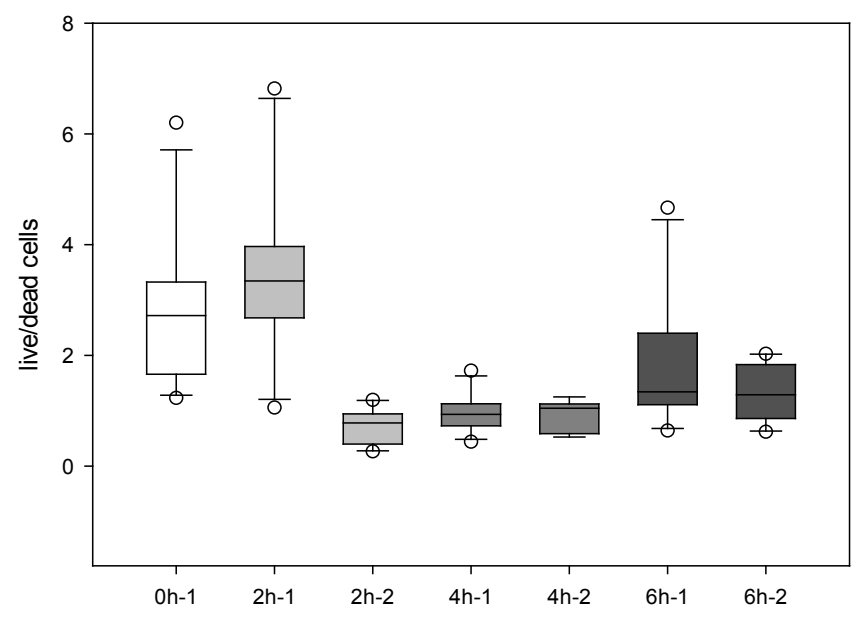

Figure 4: The ratio of live/dead cells in the control variant during the experiment 
different from the control variant discussed above. The ratio live/dead cells on the thin films looks different in comparison with the values of the control experiment. The mean values of the live and dead cells and the ratio counted from the thin films obtained by sol-gel method (SGD) show a continuous reduction in the values as can be seen in Figure 5 and Table 2 .

The cultivation method shows decreasing of viable cells quantity on SGDM thin $\mathrm{ZnO}$ films with the time. The number of the colonyforming units at the second hour is $1 \times 10^{5} \mathrm{CFU} / \mathrm{ml}$ and at the $6^{\text {th }}$ hour is $1 \times 10^{4} \mathrm{CFU} / \mathrm{ml}$ (ten times less than in the second hour). These results can be attributed to the toxic effects of zinc ions, or free oxygen radicals formed on the surface of the thin films and damages of the cell wall and external membrane during the interaction with the cells. The overall decrease in the quantity of the counted cells can be explained by the fact that damaged cells lyzed and their content can serve as a protecting agent, invisible under UV light, but helpful for other cells (Figure 5, Table 2). In visible light around the cells stained with kit, are observed some materials which are in a weak pink color similar to the material from cells' lyses. The cells contents can serve as a chelator of zinc ions and disposal of superoxide radicals on the surface of thin films.

The other tested variant is thin $\mathrm{ZnO}$ films obtained by magnetron sputtering (MS) deposition. If we consider the interaction of bacteria with the zinc oxide thin films obtained by magnetron sputtering the picture is different. There is a decrease in the proportion live/dead cells between the second and fourth hour of the experiment, but between the $4^{\text {th }}$ and $6^{\text {th }} \mathrm{h}$ it is considerably lower and the differences are unreliable compared to the cells quantity on the films obtained by sol-gel method (Figure 6). At the second hour the cells quantity is $1.4 \times 10^{5} \mathrm{CFU} / \mathrm{ml}$, at the $4^{\text {th }} \mathrm{h}$ is $9.6 \times 10^{4} \mathrm{CFU} / \mathrm{ml}$, at the $6^{\text {th }} \mathrm{h}$ is $8.3 \times 10^{4} \mathrm{CFU} / \mathrm{ml}$. Decreasing in the number of live cells on the magnetron sputtered $\mathrm{ZnO}$ films during the experiment exists, but not so fast as for the cells on the films obtained by sol-gel deposition (Table 3 ). At the second hour the cells quantity is $1.4 \times 10^{5} \mathrm{CFU} / \mathrm{ml}$, at 4 th $\mathrm{h}$ is $9.6 \times 10^{4} \mathrm{CFU} / \mathrm{ml}$, at 6 th $\mathrm{h}$ is 8.3 $\mathrm{x} 10^{4} \mathrm{CFU} / \mathrm{ml}$ as written in Table 3 .

The Kruskal-Wallis test shows significant differences between the values of ratio live/dead cells for the second, $4^{\text {th }}$ and $6^{\text {th }}$ hours $(H=29.31$, $P<0.001)$. Repetitions of the different classes are combined. Only at the fourth hour, the test of Mann-Whitney showed differences between replicas $(U=20.0, P=0.045)$, but the value of $P$ is close to the level of significance $(\alpha=0.05)$.

The Dunn's test method shows statistically significant differences in the number of live cells between the second and fourth hour and between the second and sixth hour but not in the ratio live/dead cells between the fourth and sixth hour in the experiment with the

\begin{tabular}{|c|c|c|c|c|c|c|c|}
\hline & Size & Min & Max & Mean & Std. Error & Std Dev & Median \\
\hline control-0h-1 & 11 & 1.23 & 6.20 & 2.80 & 0.42 & 1.38 & 2.72 \\
\hline control-2h-1 & 10 & 1.06 & 6.82 & 3.50 & 0.49 & 1.54 & 3.34 \\
\hline control-2h-2 & 10 & 0.27 & 1.19 & 0.71 & 0.10 & 0.32 & 0.78 \\
\hline control-4h-1 & 11 & 0.44 & 1.72 & 0.97 & 0.10 & 0.34 & 0.94 \\
\hline control-4h-2 & 9 & 0.52 & 1.25 & 0.93 & 0.09 & 0.28 & 1.05 \\
\hline control-6h-1 & 10 & 0.64 & 4.67 & 1.77 & 0.37 & 1.17 & 1.34 \\
\hline control-6h-2 & 10 & 0.62 & 2.03 & 1.34 & 0.16 & 0.51 & 1.29 \\
\hline
\end{tabular}

Table 1: Base statistics for the live/dead cells ratio for the control variant as counted from epifluorescent microscope pictures.

\begin{tabular}{|l|l|l|l|l|l|l|}
\hline & Size & Min & Max & Mean & Std. Error & Median \\
\hline SGDC-2h-1 & 10 & 0.44 & 8.19 & 4.16 & 0.95 & 2.94 \\
\hline SGDC-2h-2 & 10 & 0.83 & 2.54 & 1.66 & 0.21 & 1.01 \\
\hline SGDC-4h-1 & 10 & 0.49 & 2.00 & 0.79 & 0.14 & 0.67 \\
\hline SGDC-4h-2 & 10 & 0.11 & 2.00 & 0.73 & 0.17 & 0.45 \\
\hline SGDC-6h-1 & 10 & 0.04 & 0.75 & 0.31 & 0.07 & 0.54 \\
\hline SGDC-6h-2 & 10 & 0.05 & 1.03 & 0.28 & 0.10 & 0.23 \\
\hline
\end{tabular}

Table 2: Base statistics for live/dead bacterial cells ratio on thin $\mathrm{ZnO}$ films obtained by Sol-gel method collected from epifluorescent microscope pictures

\begin{tabular}{|l|l|l|l|l|l|l|l|}
\hline & Size & Min & Max & Mean & Std. Error & Std Dev & Median \\
\hline MS-2h-1 & 9 & 1.14 & 6.29 & 3.78 & 0.51 & 0.29 \\
\hline MS -2h-2 & 11 & 1.11 & 3.87 & 2.73 & 0.29 & 0.09 \\
\hline MS -4h-1 & 10 & 0.40 & 1.37 & 0.69 & 0.09 & 0.30 \\
\hline MS -4h-2 & 9 & 0.18 & 2.76 & 1.28 & 0.27 & 0.80 \\
\hline MS -6h-1 & 11 & 0.19 & 2.01 & 0.84 & 0.17 & 0.94 \\
\hline MS -6h-2 & 9 & 0.16 & 4.31 & 1.26 & 0.43 & 0.62 \\
\hline
\end{tabular}

Table 3: Base statistics for live/dead ratio for the thin $\mathrm{ZnO}$ films obtained by a magnetron sputter deposition. Collected from epifluorescent microscope pictures.

\begin{tabular}{|l|l|l|l|l|l|l|l|}
\hline & Size & Min & Max & Mean & Std. Error & Std Dev & Median \\
\hline CBD-2h-1 & 11 & 0.80 & 6.91 & 2.72 & 0.58 & 1.83 \\
\hline CBD -2h-2 & 4 & 3.17 & 5.44 & 3.97 & 0.51 & 1.02 \\
\hline CBD -4h-1 & 10 & 0.58 & 3.00 & 1.59 & 0.24 & 0.74 \\
\hline CBD -4h-2 & 10 & 0.36 & 5.38 & 1.73 & 0.49 & 1.63 \\
\hline CBD -6h-1 & 10 & 0.77 & 2.70 & 1.76 & 0.31 & 1.02 \\
\hline CBD -6h-2 & 10 & 0.10 & 1.66 & 0.70 & 0.18 & 0.99 \\
\hline
\end{tabular}

Table 4: Data processed with statistical program from the $\mathrm{ZnO}$ thin films obtained by chemical bath deposition.Base statistics. 


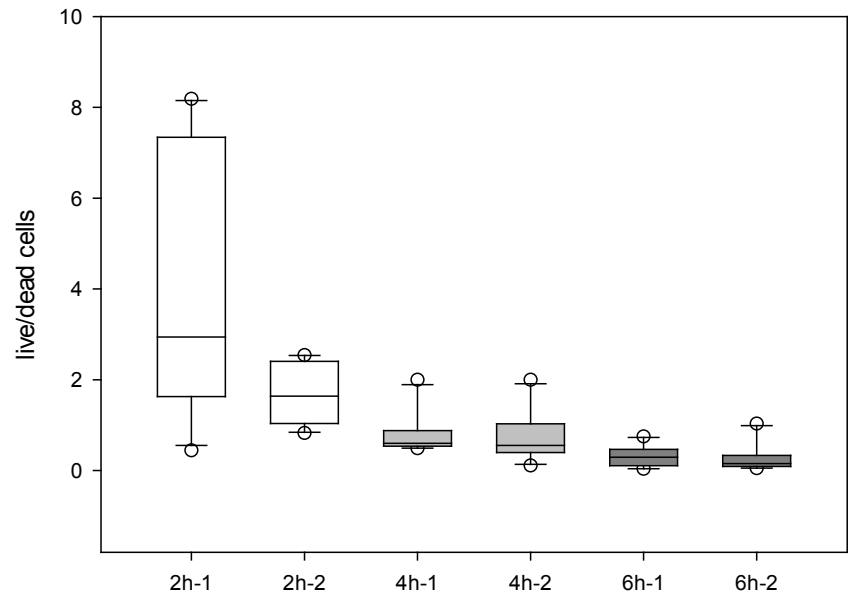

Figure 5: Ratio of the live/dead cells on the $\mathrm{ZnO}$ films obtained by sol-ge deposition method during the experiment.

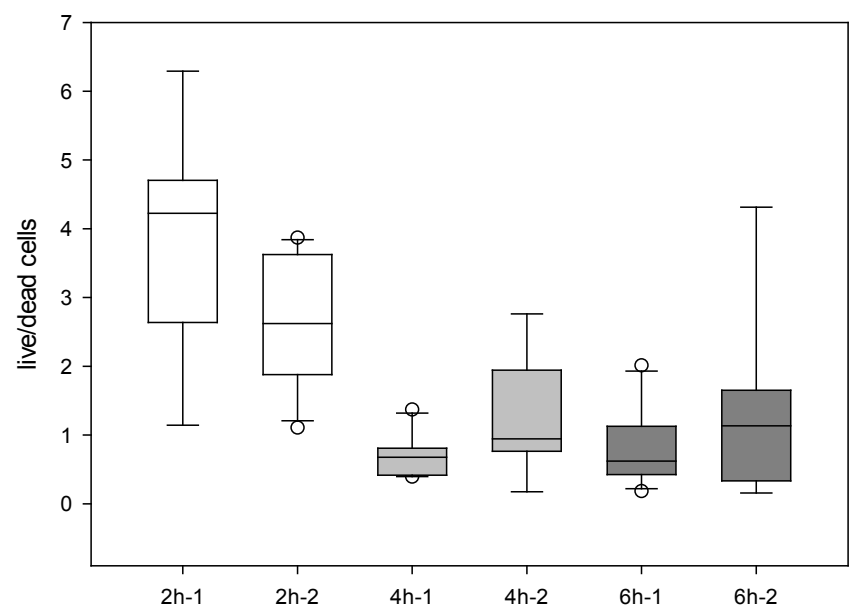

Figure 6: The ratio of live/dead cells on the $\mathrm{ZnO}$ films obtained by magnetron sputtering deposition method during the experiment.

obtained by magnetron sputtering $\mathrm{ZnO}$ films. The result means that the bactericidal effect is stronger at the first 2 hours of interaction and later it weakens. The reason may be the stability of $\mathrm{ZnO}$ thin films obtained by magnetron sputtering, thus the quantity of $\mathrm{Zn}$ ions or nanoparticles around the bacteria is low (Figure 7).

It can be assumed that the release of superoxide radicals or ions of these films, damaging the bacterial cells' membrane is expressed only at the first hour of interaction. After the 4th hour of their interaction the effect weakens or disappears. The effect does not appear in cells, washed from the thin $\mathrm{ZnO}$ films, grown in culture medium without $\mathrm{Zn}$ ions or nanoparticles.

A similar pattern of cell reaction as with films obtained by magnetron sputtering is observed when investigate the ratio of dead and live cells on thin films of zinc oxide obtained by the method of chemical bath deposition (Table 4).

Kruscal-Wallis test shows significant differences in the ratio between live and dead cells during the experiment on CBD films $(H=12.8, P=0.002)$. As with the films obtained by magnetron sputtering and these kinds of films have toxic effects on bacteria. After 4 hours there are no significant differences in the ratio between live and dead cells till the end of the experiment (Table 4).

These films show no decrease in the quantity of viable bacteria till the $4^{\text {th }}$ hour counted on agar medium. There is even increase of bacteria from zero till second hour, from $5-6 \times 10^{5}$ to $3 \times 10^{6} \mathrm{CFU} / \mathrm{ml}$ (Figure 8). At the 4 th hour the bacterial quantity is similar to that of zero hour $(3 \times 105 \mathrm{CFU} / \mathrm{ml})$, and at the 6 th hour it is $3 \times 104 \mathrm{CFU} / \mathrm{ml}$, ten times less than at the 4th hour. Obviously the effect is slow and appears at the end of the experiment. Assuming that the antibacterial effectiveness of zinc oxide thin films is a reliable indicator by which to elect the structure of sensor, it could be said that the films obtained by sol-gel deposition (SGBD) have the strongest bactericidal effect during the time of experiment.

Comparison between the two methods of counting under the microscope and cultivation on nutrient medium showed that changes in the status of the cells is demonstrated first in the microscopic picture and later manifested in the nutrient medium. In the case of films obtained by chemical bath deposition significantly decrease in the amount of live cells occurs at the fourth hour, but this is not confirmed by the results for the number of viable cells washed from thin films obtained by chemical bath deposition (Figure 8). Apparently some of the cells with compromised cell wall integrity are restored in a supportive environment free of nanoparticles or ions and give rise to colonies. So the cultivation method does not report dead cells in the fourth hour of experiment. At the sixth hour there is reliable decrease in the number of live cells counted by cultivation method, but according to the statistical program, the differences in the quantity of live and dead cells counted by epifluorescent microscopy method between
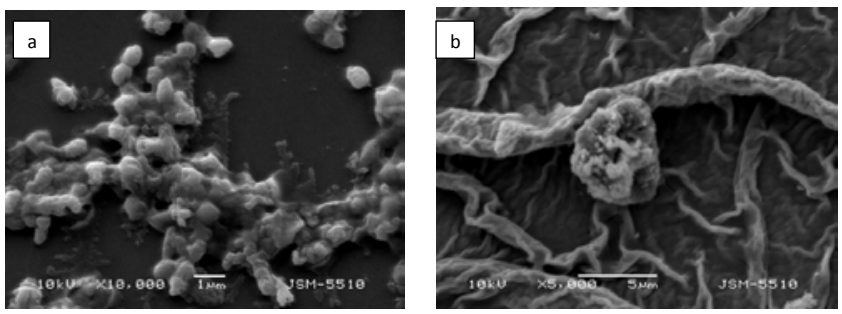

Figure 7: SEM pictures of the control variant glass (a) and thin ZnO films deposited by sol-gel dip coating (b) with Pseudomonas cells after 9 hours interaction.

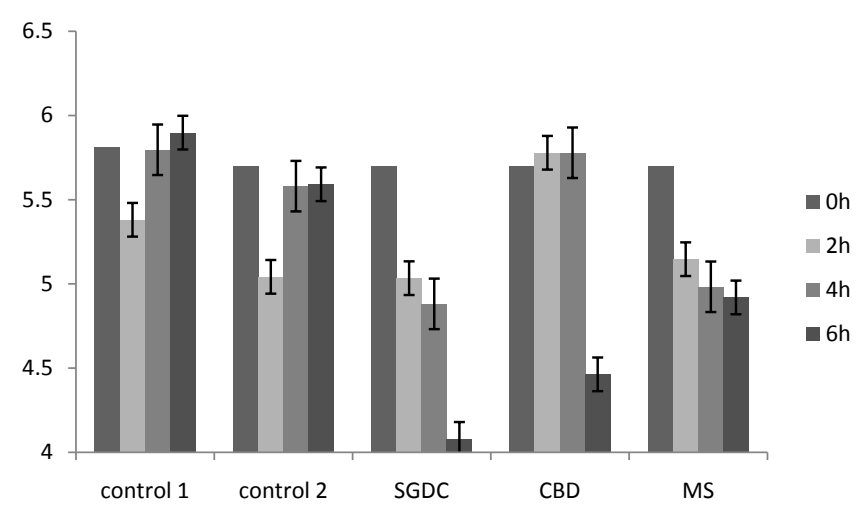

Figure 8: Changes in the number of live cells counted on nutrient agar (CFU. $\mathrm{ml}^{-1}$ ). 
the fourth and sixth hours are unreliable. Kruskal-Wallis test shows significant differences between median values of the ratio live/dead cells for the second, fourth and sixth hours $(H=12.81, P=0.002)$.

All the results obtained by two microbiological methods showed that the environmental conditions are crucial for the survival of the bacteria. The difference between the green + yellow cells, counted as live cells, and the red cells, counted as dead cells, and the number of cells in CFU/ml obtained by cultivation method is still considerable. Results from the control variant prove that in exponential phase the fast growing cells have some kind of membrane permeability to propidium iodide (PI). Obviously PI penetrates into the live dividing cells and stains them in red. This is in congruence with the research of Shi L et al. [28] on the limits of propidium iodide as a cell viability indicator for the environmental bacteria. M. Berney et al. [29], supposed the flow-cytometric pattern can be related to the presence of intermediate cellular states characterized by the degree of damage affected specifically on the bacterial outer membrane. This hypothesis is supported by the fact that EDTA-treated non-irradiated cells exhibit the same staining properties. Our observation proved that some of the red cells are moving actively, when they are directly counted on the glass slide. May be their cells' membrane is not disrupted as supposed by [30]. After cultivation on solid rich medium, these cells give the slow growing colonies, which are visible after $48 \mathrm{~h}$. These facts suggest that some of the red cells, which have been marked as dead, are viable and could restore their normal functions, giving colonies that emerge later. We proved the possibility of some sub lethal membrane damages which could bring to red staining and confusion in the results interpretation [31].

The evaluation of thin $\mathrm{ZnO}$ films by two methods is presented on Figures 8 and 9. Changes in the ratio of live/dead cells on the three $\mathrm{ZnO}$ thin films is statistically proved and the lowest values are on the film obtained by sol-gel dip coating at the second, fourth and sixth hours (Figure 9). There are no reliable differences between ratios at second hour. At the fourth hour the Kruskal-Wallis shows significant differences: $H=10.59, P=0.005$. The Dunn's Method at the same hour shows reliable differences between films obtained by sol-gel dip coating and magnetron sputter deposition, at the level of significance $\alpha=0.05$. There are reliable differences between the groups, this means that

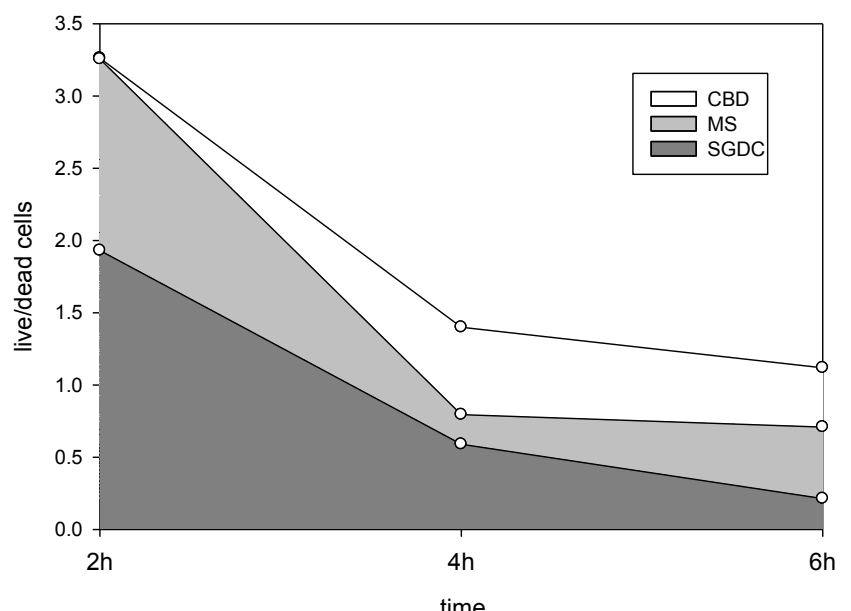

Figure 9: Changes in the ratio of live/dead cells on different films during the experiment: T- Chemical bath deposition, O- magnetron sputtering, L-sol-gel dip coating. the SGDC method has strongest bactericidal effect, the film obtained by magnetron sputtering is second and the lowest effect on bacteria has the film obtained by chemical bath deposition. The thickness of the deposited films has no reliable impact on their bactericidal effect as proved by the results at Figure 9, as the sol-gel and chemical bath deposited films have almost the same thickness.

At the sixth hour the Kruskal-Wallis test shows significant differences: $H=19.61, P<0.001$ and Tukey test - significant differences between SGDC and other films - CBD and MS at the level of meaning $\alpha=0.05$. All results prove the strongest bactericidal effect of $\mathrm{ZnO}$ thin films obtained by sol-gel dip coating method. The possible use of ZTFs in the future is the cancer therapy as proposed by Akhtar et al. [3].

\section{Acknowledgement}

This work has been supported by the Bulgarian Ministry of Science and Education, Project D002-207, 2009. We dedicate this article to the memory of Dr Ceco Dushkin, who prepared the project and gathered the working team.

\section{References}

1. Wang H, Wingett D, Engelhard MH, Feris K, Reddy KM, et al. (2009) Fluorescen dye encapsulated $\mathrm{ZnO}$ particles with cell-specific toxicity for potential use in biomedical applications. J Mater Sci Mater Med 20: 11-22.

2. Ahamed M, Akhtar MJ, Raja M, Ahmad I, Siddiqui MK, et al. (2011) ZnO nanorod-induced apoptosis in human alveolar adenocarcinoma cells via p53, survivin and bax/bcl-2 pathways: role of oxidative stress. Nanomedicine 7: 904 913

3. Akhtar MJ, Ahamed M, Kumar S, Khan MM, Ahmad J (2012) Zinc oxide nanoparticles selectively induce apoptosis in human cancer cells through reactive oxygen species. Int J Nanomedicine 7: 845-857.

4. Serpone N, Dondi D, Albini A (2007) Inorganic and organic UV filters: Their role and efficacy in sunscreens and suncare products. Inorganica Chim Acta 360: 794-802.

5. Cai R, Van GM, Aw PK, Itoh K (2006) Solar-driven self-cleaning coating for painted surface. C R Chim 9: 829-835.

6. Yuranova T, Laub D, Kiwi J (2007) Synthesis, activity and characterization of textiles showing self-cleaning activity under daylight irradiation. Catalysis Today 122: 109-117.

7. The Royal Society (2004) Nanotechnology and Nanoscience.

8. Gajjar P, Pettee B, Britt DW, Huang W, Johnson WP, et al. (2009) Antimicrobial activities of commercial nanoparticles against an environmental soil microbe, Pseudomonas putida KT2440. J Biol Eng 3: 9.

9. Franklin NM, Rogers NJ, Apte SC, Batley GE, Gadd GE, et al. (2007) Comparative toxicity of nanoparticulate $\mathrm{ZnO}$, bulk $\mathrm{ZnO}$, and $\mathrm{ZnCl}_{2}$ to a freshwater microalga (Pseudokirchneriella subcapitata): the importance of particle solubility. Environ Sci Technol 41: 8484-8490.

10. Heinlaan M, Ivask A, Blinova I, Dubourguier H-C, Kahru A (2008) Toxicity of nanosized and bulk $\mathrm{ZnO}, \mathrm{CuO}$ and $\mathrm{TiO}_{2}$ to bacteria Vibrio fischeri and crustaceans Daphnia magna and Thamnocephalus platyurus. Chemosphere 71: $1308-1316$

11. Tam KH, Djurisic AB, Chan CMN, Xi YY, Tse CW, et al. (2008) Antibacteria activity of $\mathrm{ZnO}$ nanorods prepared by a hydrothermal method. Thin Solid Films 516: 6167-6174.

12. Huang L, Li DQ, Lin YJ, Wei M, Evans DG, et al. (2005) Controllable preparation of Nano-MgO and investigation of its bactericidal properties. J Inorg Biochem 99: 986-993.

13. Li X, Huo Y, Jiang Y, Ding Y (2010) Antibacterial Activity of ZnO Films in Rice. 4th International Conference on Bioinformatics and Biomedical Engineering (iCBBE), Chengdu.

14. Li M, Pokhrel S, Jin X, Mädler L, Damoiseaux R, et al. (2011) Stability, bioavailability, and bacterial toxicity of $\mathrm{ZnO}$ and iron-doped $\mathrm{ZnO}$ nanoparticles in aquatic media. Environ Sci Technol 45: 755-761. 
Citation: Ivanova IA, Tasheva-Terzieva E, Angelov O, Krusteva L, Andonova I, et al. (2012) Effect of ZnO Thin Films on Survival of Pseudomonas Cells. J Nanomed Nanotechol 3:148. doi:10.4172/2157-7439.1000148

15. Kohen R, Nyska A (2002) Oxidation of biological systems: oxidative stress phenomena, antioxidants, redox reactions, and methods for their quantification. Toxicol Pathol 30: 620-650.

16. Kelly KA, Havrilla CM, Brady TC, Abramo KH, Levin ED (1998) Oxidative stress in toxicology: established mammalian and emerging piscine model systems. Environ Health Perspect 106: 375-384

17. Rikans LE, Hornbrook KR (1997) Lipid peroxidation, antioxidant protection and aging. Biochim Biophys Acta 1362: 116-127.

18. Xie Y, He Y, Irwin PL, Jin T, Shi X (2011) Antibacterial activity and mechanism of action of zinc oxide nanoparticles against Campylobacter jejuni. Appl Environ Microbiol 77: 2325-2331.

19. Zelibor JL Jr, Doughten MW, Grimes DJ, Colwell RR (1987) Testing for bacterial resistance to arsenic in monitoring well water by the direct viable counting method. Appl Environ Microbiol 53: 2929-2934.

20. Boteva S, Kenarova A, Traykov I, Bogoev I (2009) Biotech Biotechnol. Eq. 23/ SE, 36S

21. Boteva S, Traykov I, Kenarova A, Bogoev V (2010) Abundance and spatia dynamics of bacterioplankton in the Seven Rila Lakes, Bulgaria. Chin J Oceanol Limnol, 28: 451-458.

22. Stocks SM (2004) Cytometry, 61A, 189.

23. Dimova-Malinovska D, Angelov O, Nichev H, Pivin JC (2007) ZnO:H thin films for room temperature selective $\mathrm{NH}_{3}$ sensors. J Optoelectron Adv M 9: 248-251.
24. Kaneva NV, Yordanov GG, Dushkin CD (2010) Manufacturing of patterned $\mathrm{ZnO}$ films with application for photoinitiated decolorization of malachite green in aqueous solutions. Bulletin Mater Sci 33: 111-117.

25. Ivanova IA, Angelov O, Krusteva L, Peshkova T, Papazova K, et al. (2011) Interaction of bacteria with nanostructured $\mathrm{ZnO}$ thin films. ICNBME 2011: 320 324

26. Peshkova T, Papazova K, Dushkin C (2010) Nanoscience and Nanotechnology Coronet Books Incorporated, Philadelphia.

27. Liu LF, Barford J, Yeung KL, Si G (2007) Non-UV based germicidal activity of metal-doped TiO2 coating on solid surfaces. J Environ Sci (China) 19: 745-750.

28. Shi L, Günther S, Hübschmann T, Wick LY, Harms H, et al. (2007) Limits of propidium iodide as a cell viability indicator for environmental bacteria. Cytometry A 71: 592-598.

29. Berney M, Hammes F, Bosshard F, Weilenmann HU, Egli T (2007) Assessment and interpretation of bacterial viability by using the LIVE/DEAD BacLight Kit in combination with flow cytometry. Appl Environ Microbiol 73: 3283-3290.

30. Brayner R, Ferrari-lliou R, Brivois N, Djediat S, Benedetti MF, et al. (2006) Toxicological impact studies based on Escherichia coli bacteria in ultrafine $\mathrm{ZnO}$ nanoparticles colloidal medium. Nano Lett 6: 866-870.

31. Ivanova IA, Kambarev S, Popova RA, Naumovska EG, Markoska KB, et al (2010) Biotechnol \& Biotechnol Eq 24: 567. 